\title{
Anesthetic Services in Serbia
}

\author{
Branislava M. Majstorović1 ${ }^{1}$ Branko D. Milaković1,2 \\ ${ }^{1}$ Center for Anesthesiology and Resuscitation, Clinical Center of Serbia, Belgrade, Serbia \\ ${ }^{2}$ Medical Faculty University of Belgrade, Belgrade, Serbia
}

\section{SUMMARY}

Explanation the topic: Due to the development of knowledge and technology our world is becoming a global city where rapidly occur changes in political and economic milieu, such as the introduction of corporate capitalism in the economic crisis, contemporary migrations etc. Health care as a public good on one hand and as the highest individual value of each individual on the other hand, changes and suffers changes. Health care system policy insists on partnership relation of the individual with medical service providers. This refers to the a secure and accessible modern treatment of each individual and to the state as to rationalize and reduce medical costs with effective methods of treatment.

Topic position in scientific/professional public: Anesthesiology is evolving along with the surgical disciplines. Highly sophisticated with organized service, anesthesiology is equally important because of the multiplicity of anesthetic services in the surgical treatment of the disease in terms of teamwork and multidisciplinary treatment of the disease. The intention is to provide a description of work, education and our results in the economic, geopolitical and cultural context of the Serbian health system policy as well as to improve safe performance, availability and cost rationalization in anesthesia. The health care system is territorially organized in Serbia. In hospitals, Serbia employs 940 anesthesiologists (1:7,575 inhabitants). According to data from the Regional Medical Chamber of Belgrade,382 anesthesiologists were registered in Belgrade out of total. Anesthesia department network is well organized in all surgical hospitals. Anesthesia services are available depending on the place of residence, type of surgical illness or injury, and the distance to the nearest clinic.

Sub-specializations in the field of anesthesiology have not been introduced although pediatric, neurosurgery and cardiosurgical anesthesia have spontaniously singled, as well as other areas of anesthesia. Previously mentioned areas of anesthesiology have been defined by National and international certificates, courses of University and professional anesthetic associations.

Our results showed that the direct costs of anesthesia services combine $40 \%$ of the costs for salaries, $32 \%$ for medicines and supplies and $28 \%$ for other expenses.

Further action: Future activities in anesthesia include continuing medical education, standardization of equipment, diagnostic and therapeutic protocols.

This paper shows anesthesiology work in Serbia with a special emphasis on results.

Keywords: anesthesia, health policy, economics 


\section{Explanation the topic}

Safety anesthesia - The strategy of surgical treatment of diseases could not be implemented without the participation of the anesthesiologist in the preoperative, operative and postoperative period.

Anesthesia services include various types of general anesthesia and local anesthesia techniques. Anesthesia procedures are skills used during hospitalization: analgesia, anesthesia and other procedures. Other anesthetic procedures include controlled hypotension, a cannulation of a.radialis,v.jugularis interne, preparation and connection monitoring for the direct measurement of blood pressure etc.Only doctors specializing in anesthesiology with reanimation are permitted to provide anesthesia services in hospitals and in cooperation with the anesthesiology technicians, who are specially trained.

In the world, 230 million patients receive anesthesia for surgery every year. Of that number, 7 million patients develop complications of surgical procedures, with 1 million fatalities (200,000 in Europe) [1,2].

American Association of Anesthesiologists (ASA) made a Relative Value Guide system which determines anesthetic risk for surgical intervention, according to the general condition of the patient, the duration of anesthesia and type of surgery. Relative Value Guide increases depending on the number of organ systems that are pathological condition of the patient, such as age, malnutrition and urgency of surgical intervention or reintervention, which is used in most countries in the World $[3,4,5]$.

The risk of death during anesthesia in otherwise healthy patients (ASA I) is about 1 : 250 000. Mistakes during application of drugs in anesthesia occur in about 1 in 1,000 anesthesia services. The risk of the presence of consciousness during general anesthesia is 1: 650 . Neurological complications occur rarely during epidural and spinal anesthesia. Allergy and anaphylaxis were recorded, most commonly to muscle relaxants. Pulmonary aspiration are expected in about 1: 7,000 anesthesia, with low morbidity in healthy patients. The incidence of anesthetic complications is higher in infants compared to the adult population anesthetized patients. Serious complications of anesthesia are related to cardiovascular and respiratory systems. Anesthesia complications result in combination of different factors whereas human errors and organizational failures contribute to complications in $50-70 \%$ cases [6].

World Federation and the European Society of Anesthesiologists have made an effort to formulate the minimum international standards and to define the available resources for the safe anesthetic practice. Anesthesia services need to be available to every patient. As a final result, we have adopted The Helsinki Declaration for Patient Safety in Anaesthesiology [7], signed by our Serbian Association of Anesthesiologists. Considering the above facts, in order to improve the health and quality of life of surgically treated patients, the European Committee of Anesthesiologists has defined goals. All institutions that provide anesthesia services in Europe have to to comply with the minimum standards laid down in the operating room, and postoperative care. Standard protocols relate to preoperative preparation and verification of anesthesia equipment and drugs [8,9] evaluate the possibilities of difficult intubation, malignant hyperthermia, allergies, toxicity local anesthesia, the possibility of bleeding more than $500 \mathrm{ml}$ and infection control.

\section{Topic position in scientific/professional public}

\section{Geo-political, demographic and economic aspects of Serbia}

Serbia is an upper - middle income economy with an average monthly salary of $\$ 542$, and the overall unemployment rate of $22 \%$, with the trend of falling wages and rising unemployment.

Serbia is divided into five regions with 29 counties and the city of Belgrade, with a total of 193 municipalities. Serbia has two autonomous provinces in the north of Vojvodina (7 districts, 46 municipalities) and the south, Kosovo and Metohija (5 districts, 30 municipalities). From 2006, Kosovo and Metohija is under an international protectorate and in 2008, Kosovo and Metohija had declared independence [10].

According to the recent Census in 2011, Serbia extends over $88,407 \mathrm{~km}^{2}$ with a population of 7,120,666 inhabitants excepting Kosovo and Metohija [11]. The average population density is 125 people per $\mathrm{km}^{2}$.

The average age of populatin is 40.4 


\begin{tabular}{|l|c|c|c|c|c|c|}
\hline GDP & 2006 & 2007 & 2008 & 2009 & 2010 & $\begin{array}{l}\text { Tabele 1. GDP, GDP per capita } \\
\text { and Grow rate in \% }\end{array}$ \\
\hline GDP mil.RSD & 1.962 .073 & 2.302 .214 & 2.722 .461 & 2.815 .000 & $3,073.000$ & Data of GDP Per capita ex- \\
\hline GDP Per capita & 264.731 & 311.886 & 370.392 & 384.520 & - & $\begin{array}{l}\text { Data } \\
\text { pressed in RSD (4.138,0 Euro) }\end{array}$ \\
\hline Grow rate $\%$ & 5,2 & 6,9 & 5,5 & $-3,1$ & 1,5 &
\end{tabular}

years (men 39.1 years, women 41.7 years). Life expectancy of residents is 74 years of age (men 71 years, women 76 years) [12].

In European countries, costs for health care related to the gross national product (Gross Domestic Product-GDP) have increased, from $7 \%$ in 1990 to $8.9 \%$ in 2004 . By 2008 , the cost of GDP increased to $10.9 \%$ in Switzerland; 9.5\% in France; 9.7\% in Canada and $17 \%$ in USA [13]. According to the World Health Care Organization (WHO), in 2004, total health care cost per capita were \$917. According to the World Bank (WB), in 2005, total health care costs were $8 \%$ GDP.

In Serbia, health care costs per capita in 2011 were less than 300 euros. . The costs per capita increased from 131 euros in 2003 to 230 euros in 2007 and the costs per capita in 2008 were 255 euros $[14,15,16]$. Movement of GDP, per capita GDP and the rate of growth of GDP in Serbia is shown in Table 1.

Currently, the economic crisis is expected to decrease the expected GDP growth and the funds available for health care. Results of GDP are taken with caution, for now, it is a universal indicator for comparison of the health economy in countries. the expected GDP growth and thus the funds available for health care. Results of GDP are taken with caution, for now, it is a universal indicator for comparison of the health economy in countries. GDP does not indicate differences in the cost of living in different countries therefore considerable variations of the exchange rate in relation to the national currency mostly affect the final value of the funds. Financial organizations such as: World Bank, International Monetary Fund etc. publish variations of exchange rate annually.

Data can differ, depending on the interest of organizations that publish them.

A large part of health care resources is used for hospital costs. In Europe, during 2005 and 2006, 38\% of the funds were spent on hospital costs. In Southeastern Europe, for example in Serbia, the percentage of funds for hospital costs was $47 \%$ and $50 \%$ in Bosnia and Hercegovina [17]. Therewithal, a lower quality of service is recorded, based on the length of hospitalization. In Serbia,the average length of hospitalization ranged from 9.5 to 11 days, unlike the countries of the European Union, where the average length of hospitalization ranges from 4 to 8 days. In the European Union, the target value for the length of hospitalization is 4 days [18]. In Southeastern Europe, number of ccupied hospital beds is 5 to $10 \%$ lower than in the EU countries, where that number is $76 \%$. In the the European Union countries national bank accounts for health care have been established during 2000 and in Serbia national bank accounts for health care have been established in 2010 in order to improve control of the distribution of private and public funds for health care. Serbia's economy is based on the service industry and agricultural activities. Serbia is faced with problems of the high unemployment rate of $21.6 \%$ in the population of 15-64 years of age, national budget deficits and high level of imports compared to exports. Serbia faces a number of reforms, including health care reform on the road to the European Union. In January 2011, the average value of gross income was 47,383 RSD (EU 460) [19].

\section{Serbian health system}

The health care system of Serbia suffered four reforms and Bismarch's economic model is in force since World War II. Health care system is financed through compulsory health insurance that covers the largest part of the population (96\%) with dominant state control of medical equipment and facilities. 91\% of funds are raised from salary contributions , 7\% from government budget grants and $2 \%$ from miscellaneous revenue such as participation, donations, private insurance, local community resources, etc. The collection and spending of funds should be internal and public $[20,21,22]$.

From the end of 2012, financing primary health care is realized by capitation method. Therefore, for example, personal income of general practitioners is calculated according to the number of treated patients, the price of drugs, etc. The "Official Gazette" states the name and amount of drug, related to the 
diagnosis of the disease, which a general practitioner can prescribe to patients.

Secondary and tertiary health care per patient treated or diagnosis related groups of diseases (DRG) financing is acceptable for countries with high and middle-income such as the countries of Western Europe [23]. Theoretically, this issue is related to a system that should objectively evaluate the health services provided by physicians in the secondary and tertiary health care. In Serbia, the previous practice of paying health care providers upon treatment was not able to recognize all aspects of the treatment of the disease because such practice does not approve the existence of comorbidity and complications, but only the average cost of treatment. DRG system consists of provided diagnostic and therapeutic procedures along with the diagnosis, comorbidities and complications and coded nomenclature, calculated according to the coefficient of already formed DRG for this episode of hospital treatment, on the basis of which the payment is made to hospitals. The standard price of the service does not have to be correlated to the actual costs of treatment.

Modern approaches to financing health care are envisaged through contracts between those who pay service and service providers as well as public tender.

Serbian health care system is organized on two levels, for individuals and families, including:

1. primary health care (health centers, home care services, ambulance, diagnostic laboratories, dentistry, pediatrics);

2. secondary (specialist services in hospitals);

3. tertiary (specialized hospitals, clinical centers).

Primary health care covers 2,000 to 50,000 population, secondary 100,000 to 500,000 population and tertiary $5,000.000 .000$ 500,000 population, including scientific research [24].

In Serbia, Health Care Institutions Action Plan regulates the number, structure, capacity and special distribution of health care institutions. The capacity of tertiary health institutions (6,000 hospital beds, or 0.8 beds per capita) is arranged according to the number and density of inhabitants who need special medical care, taking into account the infrastructure capacitities [25].

In 2006, 20,157 physicians were registered, of which 15,317 have been medical specialists ( 1 physician per 368 population) [26]. The hospitals had 6,372 specialist doctors employed, of which there were 940 anesthesiologists. According to data of the Regional Medical Chamber in Belgrade, taking in account the total number of anesthesiologists, 382 were registered anesthesiologists in Belgrade. The hospitals had 6,372 specialist doctors employed, of which there were 940 anesthesiologists. According to data of the Regional Medical Chamber in Belgrade, taking in account the total number of anesthesiologists, 382 were registered anesthesiologists in Belgrade. Setting the hospital information system of bookkeeping is in progress and Regional Medical Chambre in Belgrade does not have available accurate data for other regions of Serbia.

\section{Anesthesia and anesthesiological service}

Patients in need of anesthesia for surgery or those who have the deteriorated condition and need monitoring, support and/or restitution of vital functions primarely after stabilization of circulatory volume are refered to further hospital treatment by doctors in primary care or specialist doctor of emergency medicine.

Anesthesiological services begin from secondary health care in anesthesia and resuscitation ambulance. Emergency health care services and outpatient clinics are also entry points of patients in the hospital health care system. The responsibility of the anesthesiologist begins in reanimation ambulance, carefully observing patients in the preoperative, operative and postoperative treatment period to the point when patients get released from the hospital. Necessary biochemical and hematological analysis, radiological and ultrasound diagnostic procedures are performed at secondary level of treatment. Tertiary health care level includes specific and highly specialized surgical interventions and treatment of complicated diseases and injuries of vital organs.

The anesthesiologist is responsible for safety and quality in anesthesia, intensive care unit, including the preoperative period and many other specific situations in the hospital and outside of it, where patients are vitally affected.

The studies $[27,28]$ show calculated costs per anesthesia. Anesthesia is administered by standard procedure and calculated 
by the hour, and the duration of anesthesia for surgery. Anesthesia for surgery includes an introduction,surgical procedure time and awakening from anesthesia.

Retrospective and descriptive study of our authors show that the direct costs make up $40 \%$ of the expenses for salaries (personal expenses, $32 \%$ for medicines and supplies and $28 \%$ for other expenses [29-31]. The direct expenses of anesthesia would enlarge the surgical operating costs for $10 \%$ if counted as an element of clinical support to center of consumption, ie. surgical expenses [32].

The direct costs are the only costs of anesthetics, drugs and material costs realistic, transparent, subject to check and change and all the other elements are determined by law and the annexes to the agreement with the Republic Institute for Health Insurance.

Further cost reductions of anesthesiological services and consumption of drugs are limited $5.93 \%$ of total drug spending in KCS) [33] for endangering the choice of type and technique of anesthesia in terms of the extremely restrictive budget for health care.

Online Documentation of material (direct) costs better correlates with expenses through predefined standard methods of anesthesia, 90.3\% (Pearsson correlation coefficient 0.77 ) in respect to the distribution of material costs, which is performed retrospectively on the basis of data collected in the electronic system of anesthesia (49.1\%) [34]. Most financial analysis regarding price of anesthetic responsibilities outside the operating room are debatable. Length (hours per case; $h /$ case) and the type of surgery (ASA base units per case; base/ case) determines the anesthetic service [35].

\section{Education and continuous medical education of anesthesiologists}

Basic medical knowledge is acquired at the Medical Faculty in Belgrade, Novi Sad, Kragujevac, Nis and Pristina. The first private School of Medicine was accredited in 2005. License for doctors was introduced in 2008 and on an annual basis, in 2010 were specified criteria and procedures of Continuing Medical Education for license renewal .

Since 2010, specialization of anesthesia and resuscitation takes five years, although there are requirements to return to the previous duration of four years.

In the departments of anesthesia,
Emergency Center and Intensive Care Unit, mastering practical clinical skills and various surgical disciplines such as pediatrics, general surgery, neurosurgery, cardiac surgery, ophthalmology, Otorhinolaryngology (ENT), etc. is enabled under the supervision of a mentor.

Colloquiums in certain fields take place at the end of certain period of practice spent in anesthesiology departments dealing with anesthesia, which is the subject of tests.

The final examination is composed of practical and oral part. Practical part is done by administering anesthesia for surgery. Oral part consists of assessment tests taken in the presence of anesthesiology committee. Required literature is written by our and foreign authors (mostly English speaking).

Continuing Medical Education was organized and introduced few years ago by the Faculty of Medicine, Serbian Medical Society, Regional Medical Chambre and professional organization of anesthesiologists. Knowledge and results of the work are compared with those in the region and developed countries and presented by local and international courses, seminars and congresses.

Doctors improve personal medical knowledge by participating in national and international conferences and scientific literature in written and in electronic form.

\section{Where do we stand now?}

In Serbia, concept of the health care system is composite. Concept of health care system is based on contributions and mandatory health insurance funds and is part of the so-called non-profit health insurance. The positive aspects of this model are: general availability, a high level of solidarity and cost control. Negative aspects are: sluggishness offer, rationalization, waiting lists and bureaucratic legacy. This model is popular not only in countries of former Yugoslavia but also in countries with expressed social tradition such as: Austria, Switzerland, France, etc. The European models show more solidarity and are cheaper and more attractive than the US model. Hence, voluntary health insurance shall not reach the level of dominance over public health insurence [36].

Education and training of anesthesiologists in Serbia is satisfactory. Anesthesia departments provide services to the surgical departments and clinics. Number of anesthesi- 
ologists, regional distribution and equipment in anesthesiology department such as anesthesia machines, anesthetics and drugs shall be improved in future.

Anesthesia clinics that provide ambulance for preoperative preparation of surgical patients could be organized for the planned surgical procedure and daily hospital could be rendered for a shorter surgical interventions. This results in providing a better service, planning, equipment, medical personnel and other resources for operating rooms.

Better preoperative strategy and direct communication of users and health care providers with the founders of health institutions and other government organizations could help to improve the quality of provided services. The founders of health institutions are required to provide adequate resources for the service of anesthesia department and on the other hand anesthesiologists are required to safely carry patients through surgical intervention and treatment.

Interview with the patient, medical records and laboratory analysis necessary for anesthesia and physical examination provide information about patient's health. The patient is given information about anesthesia and the written consent from a patient is required for the anesthetic service.

In economic terms, anesthesia is clinical support to surgical activities due to performing diagnostic and/or surgical intervention and treatment of patients. Therefore, good cooperation between anesthesiologists and surgeons is particularly important. Reliable clinical team and, if necessary, consultants of various fields of medicine are available to the anesthesiologist in operating room and beyond.

Cooperation as team work with Clinical pharmacologists trained through specialization of Clinical Pharmacology is especially beneficial for pharmacotherapy, clinical studies and pharmacoeconomics. Furthermore, anesthesiologists may take the subspecialization in Anesthesia Clinical Pharmacology.

Industrial partners, anesthesia equipment, production and supply of anesthetics and drugs play a significant role in the development of anesthesia.

Anesthesiologists are very active in education due to performing the vital functions, especially of the heart, lungs, and the other vital organs. Anesthesiologists are active members of the fallowing international professional associations: World federation of Societies of Anesthesiologists, European members of Anesthesiologists, European and international associations for pain therapy, nutritional support, intensive therapy and regional anesthesia.

Anesthesia faces nowadays challenges of the new knowledge, research and technical innovation.

\section{Further action}

Continuous reforms of the health care system are performed in order to change the system of payment for services in conditions of economic crisis No matter how small the cost of anesthesia, because of the multiplicity of services, small savings may reduce direct costs.

Health policy measures of rationalization and cost reduction include:

1. cost management (reduction of supply in the form of insufficient budget, standardization, control);

2. the opening of the market (free choice of doctors, method of payment, the privatization of institutions and insurance);

3. changes of the structure and organization i.e. management (decentralization and the introduction of management in health care);

4. self-protection, and

5. the primary protection (selective and preventive).

In addition to these general measures for improving the work of anesthesiologists, we believe that we should take direct measures to improve the quality and safety of anesthesiology services. Direct measures to improve the quality and safety of anesthesiology services shall include:

1. introducing standards for equipment and work in the operating room, hall premedication and the intensive care units;

2. checklist for equipment and labor for certain anesthesia apparatus and procedure; 3 of the Universal lists and algorithms for preoperative preparation and anesthesia;

4. for a better evaluation and monitoring of service, individual data input and payment of all provided anesthesia services.

\section{REFERENCES}

1. Weiser TG, Regenbogen SE, Thompson KD, et al. An estimation of the global volume of surgery: a modelling strategy based on available data. Lancet 
2008;372:139-144.

2. World Federation of Societies of Anaesthesiologists. 2008 International Standards for a Safe Practice of Anaesthesia. Available on: http://anaesthesiologists.org/en/safety/2008-internationalstandards-for-a-safe-practice-of-anaesthesia.html. Accessed February 28,2011.

3. Abouleish AE, Prough DS, Whitten CW et al. Comparing clinical productivity of anesthesiology groups. Anesthesiology, 2002; 97: 608-15

4. American Society of Anesthesiologists. 2002 Relative Value Guide: A Guide for Anesthesia Values. Park Ridge. Illinols. American Society of Anesthesiologists, 2002.

5. Palmetto GBA.com-Providers/ Part B Carrier/ Ohio/Articles/Surgery/Anesthesia:Base \& Time Units. CMS Pub. 100-04, Chapter 12, Section 50:htpp:/cms.hhs.gov/manuals.

6. Fasting S. Risk in anaesthesia. Tidsskr Nor Laegeforen. 2010;130(5).498-502. (Article in Norwegian).

7. Mellin-Olsen J, Steander S, Whitaker DK, Smith AF. Helsinki declaration on patient safety in anaesthesiology. Eur J Anaesthesiol 2010; 27(7):592-596.

8. Gaba D. Anaesthesiology as a model for patient safety. BMJ 2000;320:785-8.

9. Mellin-Olsen J, O'Sullivan E, Balogh D, et al. Guidelines for safety and quality in anaesthesia practice in the European Union. Eur J Anaesthesiol 2007; 24:479-482.

10. History of Serbia. Available at: http//www.rastko.org.rs/istorija/. Accessed February 28,2011.

11. Serbia on line. Available at: http//www.srbija. cu. Accessed February 28,2011.

12. Statistical Office of the Republic of Serbia. Population changes. Available at: http://www.statserb.sr.gov.rs. Accessed February 26,2011.

13. Keehan S. Health Spending Projections Through 2017, Health A Exclusive W146: 21 February 2008.

14. Serbia. National Health Accounts (NHA). The Ministry of Health. Belgrade. 2006.

15. Gross Domestic Product of Republic of Serbia2007. Available at: htpp://www.seenews.com/ news/latestnew/serbiaeyes/opctincreaseingdpfor2007-16461. Accessed December 19,2008.

16. Orosz, Morgan D. SHA-Based National Health Accounts in Thirteen OECD Countries: A Comparative Analyses (OECD Health Working Papers No.16). 2004.

17. The Word Bank: Bosnia and Herzegovina: Public Expenditure and Institutional Review. The World Bank. June 2006.

18. Upper Middle Income Economics. Available at: htpp: / /web.worldbank.org/wbsite/external/data/ statistics/0contentMDK:20421402. Accessed December 19,2010.

19. Gross Domestic Product of Republic of Serbia2007. Available at: htpp://www.seenews.com/ news/latestnew/serbiaeyes/opctincreaseingdpfor2007-16461. Accessed December 19,2008.

20. Statistical Office of the Republic of Serbia. Salary 2011. Available at: http:/webrzs.statserb.sr.gov. rs./axd/index. Accessed February 28,2011.

21. Bjegović V, Simić S, Kosanović R. Appropriate Health Policy as Prerequisite for Health Care System Reform. In: Simić S, ed. Basis for the Health Care Reform in Republic Serbia. Belgrade: SAMIZDAT B92;2001:69-98.

22. Bjegović V, Vuković D, Terzić Z, Milićević MS, Laaser UT. Strategic Orientation of Public Health in Transition; an Overview of South Eastern Europe. J Public Health Policy. 2007;28:94-101.

23. Meyer JT,Reissmann H, Schuster M, Raetzell $M$, Rosler L, Petersen F, et all. Realisation of material costs in anaesthesia. Alternatives to the reimbursement via diagnosis-related groups. Anesthesist 2007; 56(4):353-62, 364-5

24. Grbić D, Terzić Z, Vuković D. Finansiranje sistema zdravstvene zaštite. U: Podrška reformi sistema zdravstvene zaštite i postizanju održivog finansiranja. Institut za socijalnu medicinu Medicinskog fakulteta Univerziteta u Beogradu. Fond za otvoreno društvo Srbije. Beograd, jun 2004;71-105.

25. Institute for Public Health of Serbia "Dr Milan Jovanović Batut" Health Care Statistical Yearbook 2007. Belgrade: Health Care Information System Center; 2008.

26. Medical Workers and Co-workers. Available at: http: / / www.yusurvey.co.yu/products/ys/showSummaryArticle.php? Accessed February 28, 2011.

27. Rene'e J.G.Arnold editor, Pharmacoeconomics: from theory to practice. New York. Taylor \&Franis Group; 2010.

28. Davis RE, Jacklin R, Sevdalis N, Vincent CA.Patient involvement in patient safety: what factors influence patient participation and engagement? Health Expect 2007; 10: 259-267.

29. Majstorović BM, Kastratović DA, Vućović DS, Milaković BD, Gojković-Bukarica LjČ, Pekmezović TD. Farmakoekonomska procena troškova u anesteziologiji (Pharmaco-Economic Estimation of Cost in Anesthesiology). Pharmaca Serbica 2009;1(1.2):3640.

30. Majstorović BM, Simić S, Milaković BD, Vucović DS, Aleksić VV. Descriptive analysis of work and trends in anaesthesiology from 2005 to 2006: quantitative and qualitative aspects of effects and evaluation of anaesthesia.Srp Arh Celok Lek. 2010 SepOct;138(9-10):624-31. Serbian.

31. Majstorović BM, Kastratović DA, Vučović DS, 
Milaković BD, Miličić BR. Operating cost analysis of anaesthesia: activity based costing ( $A B C$ analysis). Srp Arh Celok Lek. 2011 Jul-Aug;139(7-8):501-8. Serbian.

32. Majstorović BM, Milaković BD, Kastratović DA, Milićić BR, Vucićević VR.

Reductions in anesthesia direct costs is not the right way for racionalization of anesthesia costs. Med Pregl. 2012 Sep-Oct;65(9-10):421-7. Serbian. PubMed PMID: 23214337

33. Majstorović BM, Kastratović DA, Milaković BD, Marković SZ, Mijajlović MS, Vucović DS. Cost of anestetics and other drugs in anesthesia. Med Pregl. 2012;65(1-2):30-4.

34. Farrar S, Yi D, Sutton M, Chalkley M, Sussex J, Scott A. Has Payment by Results affected the way that English hospitals provide care? A differencein-differences analysis. British Medical Journal, 2009;339-47.

35. Dexter F, Thompson E. Relative value guide basic units in operating room scheduling to ensure compliance with anesthesia group policies for surgical procedures performed at each anesthetizing location.AANA J. 2001 Apr;69(2):120-3.

36. Polisy Research Working Paper 4374. Sustainability of Healthcare Financing in the Western Balkans:An Overvief of Progress and Challenges. Caryn Bredenkamp, Michele Gragnolati. The World Bank. Europe and Central Asia Region. Human Development. October 2007. 


\title{
Anesteziološke usluge u Sbiji
}

\author{
Branislava M. Majstorović1, Branko D. Milakovićn $c^{1,2}$ \\ ${ }^{1}$ Centar za anesteziju i reanimaciju, Klinički Centar Srbije, Beograd, Srbija \\ ${ }^{2}$ Medicinski fakultet Univerziteta u Beogradu, Beograd, Srbija
}

\section{KRATAK SADRŽAJ}

Tema: Zahvaljujući razvoju znanja i tehnologije naš svet postaje globalno mesto gde se ubrzano dešavaju promene političkog i ekonomskog miljea, poput uvođenja korporativnog kapitalizma, u uslovima ekonomske krize, savremenih migracija itd. Zdravstvo kao javno dobro, s jedne strane, i najveća individulna vrednost svakog pojedinca, sa druge strane, menja se i trpi promene. Insistira se na partnerskom odnosu pojedinca sa davaocima zdravstvenih usluga. To se odnosi na očekivanja svakog pojedinca, na bezbedno i dostupno savremeno lečenja a države, da smanji i racionalizuje medicinske troškove uz efikasne metode lečenja.

Pozicioniranje teme u naučno-stručnoj javnosti: Anesteziologija se razvija uporedo sa hirurškim disciplinama. Visoko sofisticirana, servisno organizovana, značajna je i zbog mnogobrojnosti anestezioloških usluga u lečenju hirurških bolesti u uslovima timskog rada i multidisciplinarnom lečenju bolesti. Namera nam je da pružimo opis rada, edukacije i naše rezultate u ekonomskom, geopolitičkom i kulturnom okviru zdravstvenog sistema Srbije, kako bi poboljšali bezbednost, raspoloživost i racionalizaciju troškova u anesteziji.

Sistem zdravstvene zaštite Srbije je teritorijalno organizovan. U bolnicama Srbije je zaposleno 940 anesteziologa (1:7575 stanovnika). Od ukupnog broja, registrovano je 382 anesteziologa u Beogradu, prema podacima iz Regionalne lekarske komore Beograda. Mreža anestezioloških odeljenja je dobro organizovana u svim hirurških bolnicama. Anesteziološke usluge su dostupne u zavisnosti od mesta stanovanja, vrste hirurške bolesti ili povrede i rastojanja do najbliže klinike.

Subspecijalizacije iz domena anesteziologije nisu uvedene, ali se spontano izdvojila pedijatrijska, neurohirurška i kardiohiruruška anestezija, kao i druge oblasti anestezija. Nacionalnim i internacionalnim sertifikatima i kursevima Univerzitetskih i strukovnih anestezioloških udruženja su definisane navedene oblasti anesteziologije.

Naši rezultati su pokazali da direktni troškovi anestezioloških usluga objedinjuju 40\% troškova za plate zaposlenih, $32 \%$ za lekove i materijal i $28 \%$ za ostale troškove.

Buduće aktivnosti: Buduće aktivnosti u anesteziji uključuju kontinuiranu medicinsku edukaciju, standardizaciju opreme, dijagnostičkih i terapijskih protokola, razvoj novih subspecijalizacija.

Ključne reči: anestezija, zdravstvena politika, ekonomija 